Shanti Volunteer Association

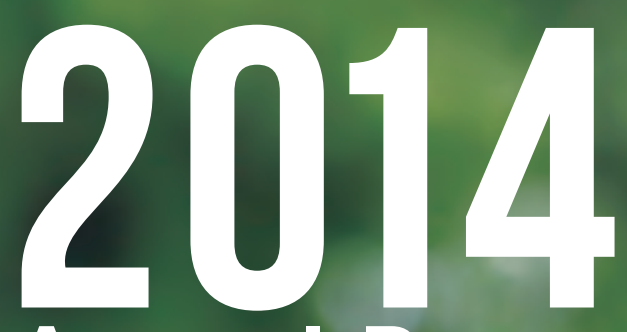
Annual Reprt

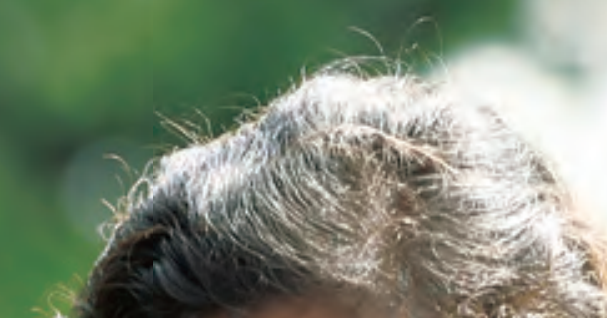


|3projects/

Providing

Opportunities of 1 Reading Books

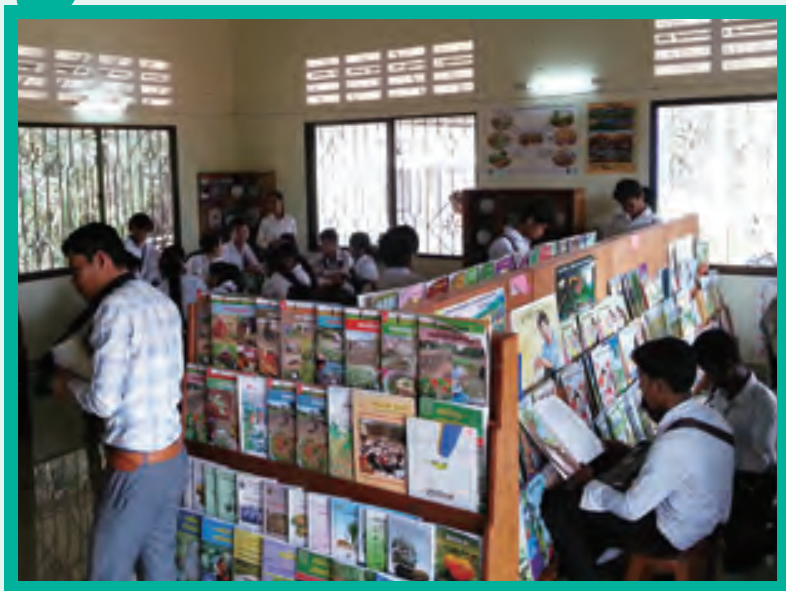

Reading books encourages children's mental growth just as tical benefits like pleasure, usefulness, and enlightenment reading various picture books or listening to many stories will develop the ability and confidence to work on things, and courage and hope to cope with difficulties.

Reading books also give children precious opportunities of getting to know characters. Literacy enables children not also to acquire knowedge by learning about the history and culture of their own and other countries.

The SVA's activities are based on the belief that "the power of books" is linked to "the power to live." Our activities include publishing picture books and picture-card shows, and purchasing books for the counties where children have various opportunities for children to meet books acting up to the situation and the need for educational support in the target countries. For example, we remodel unutilized classrooms into libraries, promote the use of book boxes whic also function as bookshelves, build community libraries, and operate mobile libraries using minivans equipped with book-

\section{Developing Human Resources}

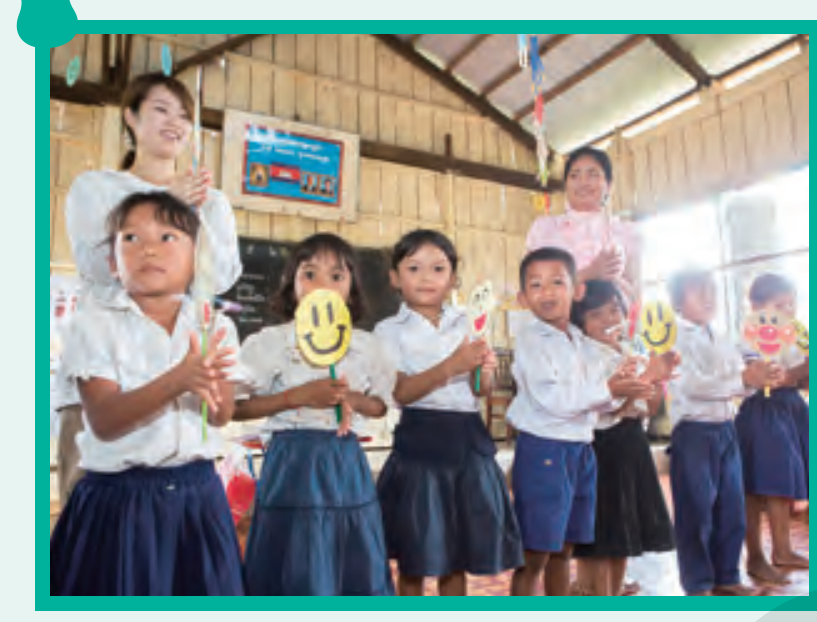

In order to increase opportunities for children to meet and read books, it is necessary to build libraries that will be loved and widely used by children. Above preparing facilities and equipment, it is critical to develop "human resources" that for librarians, childcare workers, teachers, principals, and administrators, to learn the history and the genre of picture selecting and organizing books. Maintaining an active library with constant visitors requires not only the motivation and the skill of librarians but also the support from related organizations. Therefore it is also important to develop school ance to the libraries.

Our seminar includes practicing skills such as storytelling and picture-card shows. Not a few librarians and teachers express embarrassment or reluctance to storytelling at first, but they gradually understand its necessity and pleasure
through their own experience of storytelling to children.

We also provide training programs for authors, painters, and yet penetrated in many of the aided countries, and he before publication is to find and develop creators of picture books.

As one of our activities for that purpose, we hold picture in the cants in refugee camps. There are many people creative activities. Evaluating the works of art at the contes provides a good opportunity for those people to better un derstand picture books and develop an eye for appreciating staff and administrators who will provide support and guidation is worse for picture books. The first thing we should $d$ -
Creating a Place of Peace for Children

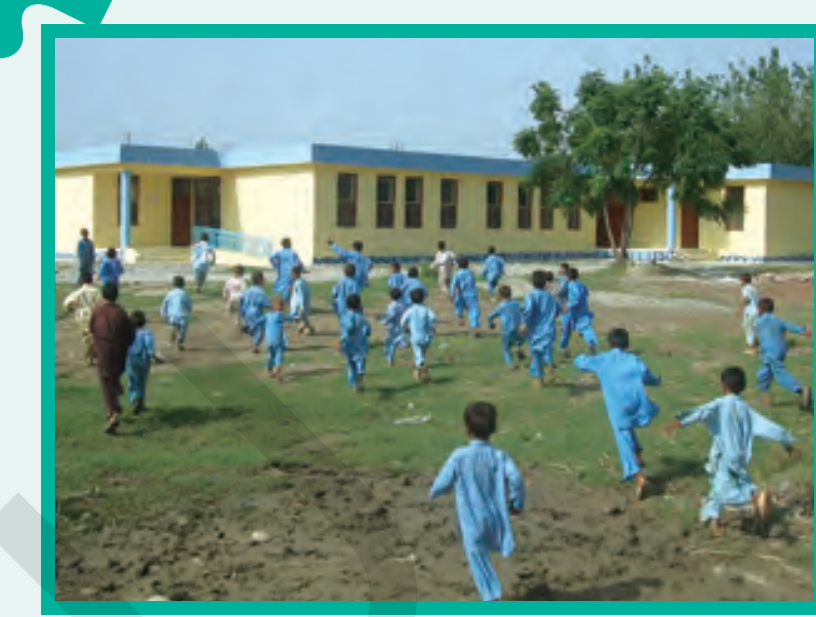

War and poverty deprive children of their smiles. These chitren come to the libraries, open picture books, and listen to storytelling, they show an innocent, child-like face with a beaming smile. For the children who are mentally hin by war and violence, libraries are childishess. We have also ben working han to niccsity and effects of education by actively holdingey such as exhibitions and opening libraries to local residents. Libraries can be expected to become a place for improving people's understanding and awareness for education.

Besides its original roles such as storing books, providing oppoks, a librery also functions as a public space for cicture ing aduls together, just like a community center or a public hall. In a case where construction of a new library inspired people living in a slum to work hand in hand to build a nursery by themselves, we provided support and advice for sus tainable management of the nursery.

In addition to the library projects, the SVA has constructed dren to live and study in safety. A project called "Children's House in Asia," in which we supported the construction and management in Cambodia and Laos, was later handed over to the local people or became a model for children's centers organized by the government.

Prolonged conflicts, poverty, and repeated natural disasare necessary to live on, and bring them felings of sorrow and hatred in return. It's no exaggeration to say that these situations can provide a hotbed for terrorism, which is now hreatening the world peace. What we can do is to stand by the people in grief, share their grief, and together seek a way to resolve the slualion, and to continue our support children by promoting the projects for boek-roaling and operating libraries. Believing that the power of books is the power to live, we will continue to create hope for the future.

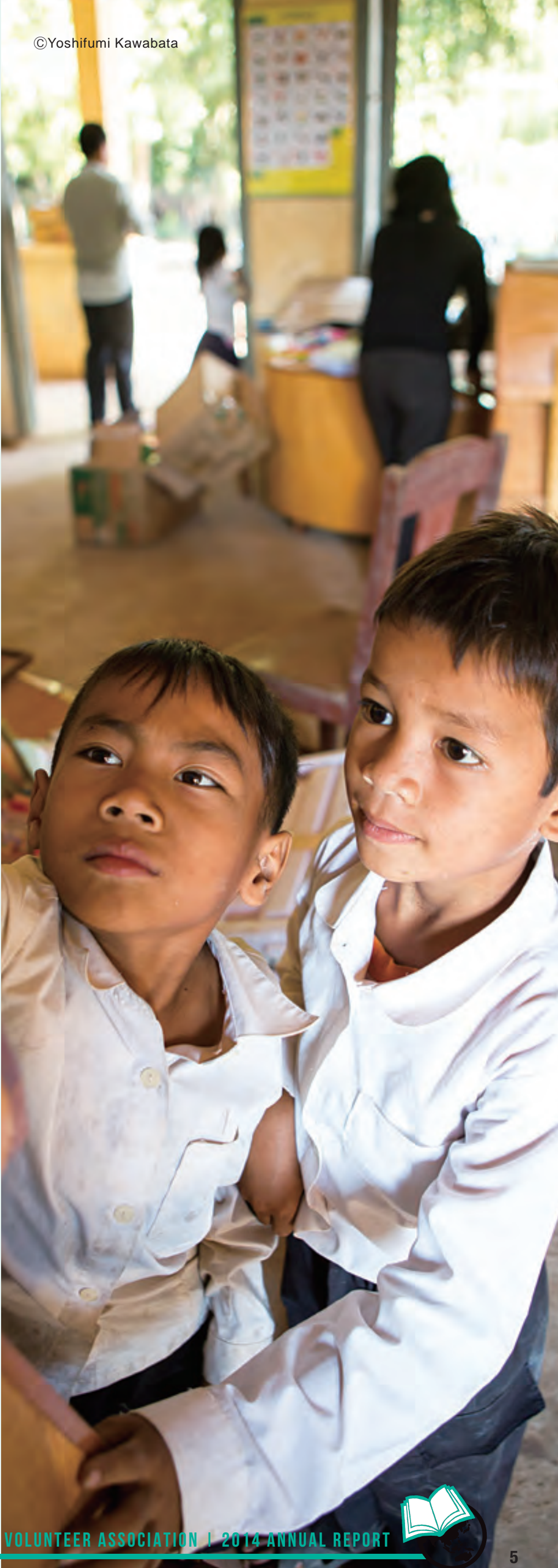




\section{To All of You}

would like to extend my heartfelt gratitude to all of you who are supporting Shanti's

This year, the Sikkha Asia Foundation (SAF) has started to operate independently in accordance with its own self-supporting plan. I would like to express my profound gratitude for your more than thirty years of support which made it possible, and also would like to ask for your continued support in the future. 2015 will be a year of challenges as well as rapid progress for the local staff.

In 2014 we were able to open a local office in Myanmar. Though the political situation urned democratic, children are still facing great difficulties. When I visited Myanmar last year, I observed "the night elementary school." Looking at the children diligently taking notes in small letters under dim lights, I not only felt their desire to find hope for future in learning, but also could not help praying for them to overcome various hardships in their future.

The SVA is aiming at realizing a peaceful society in which everybody can live with dignity. It may seem like an endless journey, but as long as there are people who will support us, we would like to walk together with them.

I sincerely ask for your continued support in the future. activities, and I hereby present our annual report for 2014

\section{To Open a Book is to Open up Your Future}

There are many children in the world who don't know what a book is, just because they were born in a different environment.

The Shanti is conducting library activities for the children in Asia who are in difficult and vulnerable positions, so that they can live with hopes for their future.

Having books is a right given equally to everyone.

Please support them with us.

For the children who have yet to know what a book is.

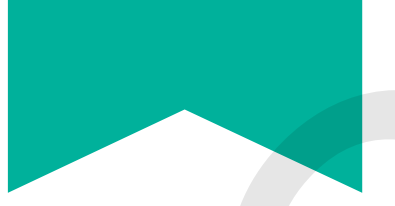

Afghanistan

In 2014, the Shanti came to several major turning points. This was the first year of a five-year plan that aims for "delivery of reading promotion activity and library activity to 6.7 million people by 2018 ," so that the people in more difficult and vulnerable positions can gain the ability to think for themselves and solve the problems on their own.

Let us turn our eyes to each country. In Thailand, where we first started our activities, the SAF, our local corporation, became independent as an NGO that solves various social problems on its own. The SAF has started anew as a partnership corporation that shares the same principles and learns together with us. In Myanmar, where we started new activities for the first time in ten years since Afghanistan, we were able to started new activities for the first time in ten years since Afghanistan, we were able to
open a local office and start full-scale programs that utilize our experiences. In Japan, 1,500 people became new support members of the Shanti.

These achievements and new challenges after 33 years of work would have been impossible without the continuous help of our supporters in various forms and opportunities up until now. All of us at the Shanti would like to send our most sincere thanks to the supporters; we have been able to continue our activities until now because we were supported by thoughts and action of each one of you and encouraged by your warm words.

We sincerely hope and ask that you will continue to walk together with us towards the goal of "realizing a peaceful (Shanti) society."

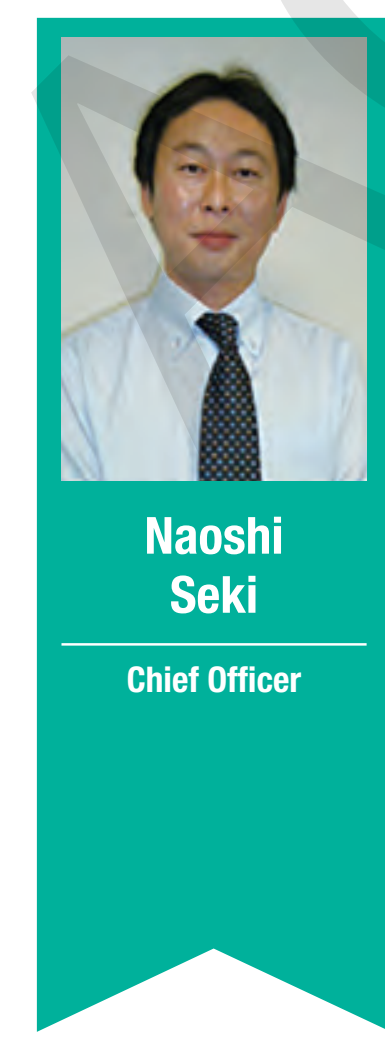

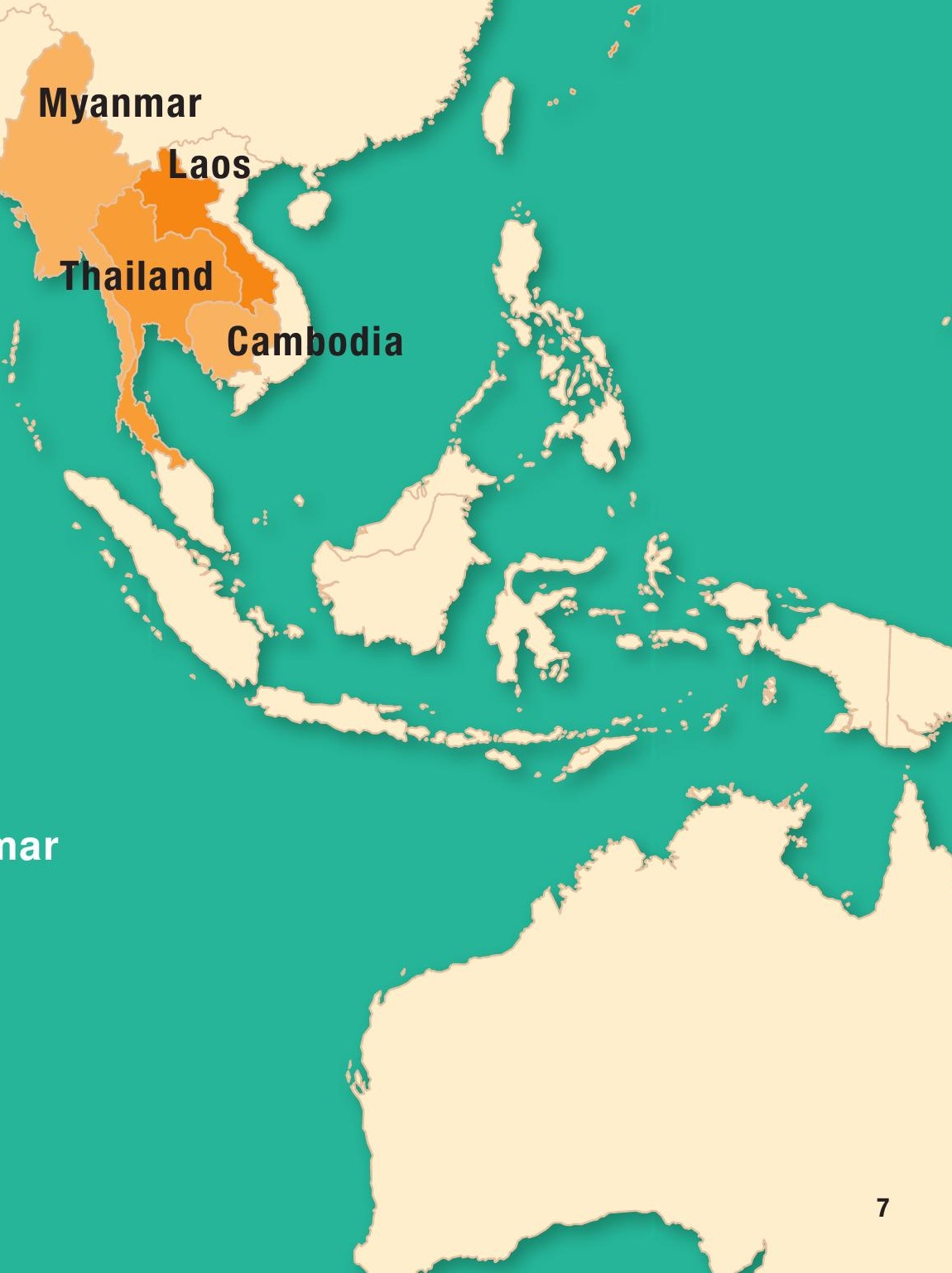




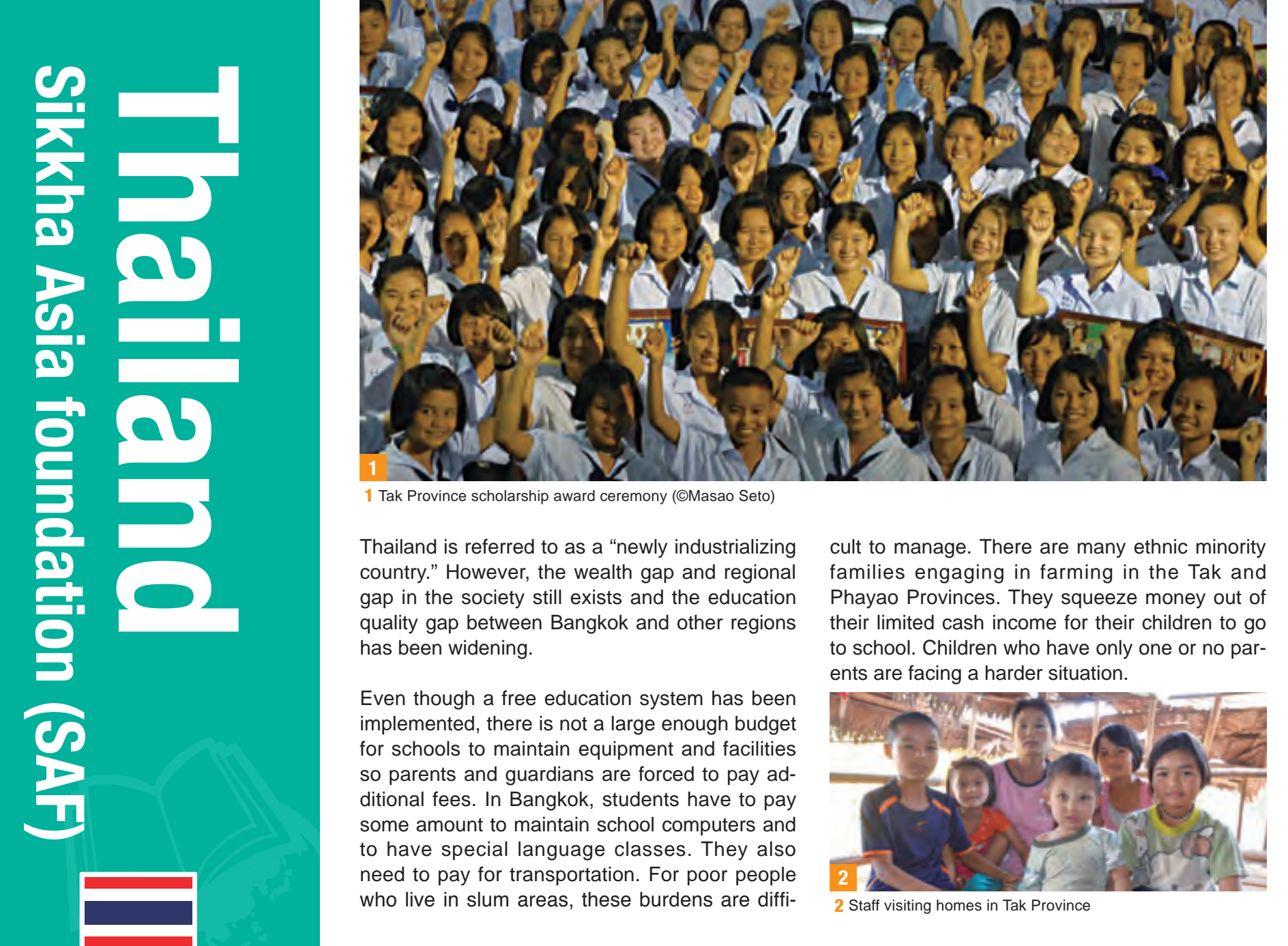

\section{Main Achievements}
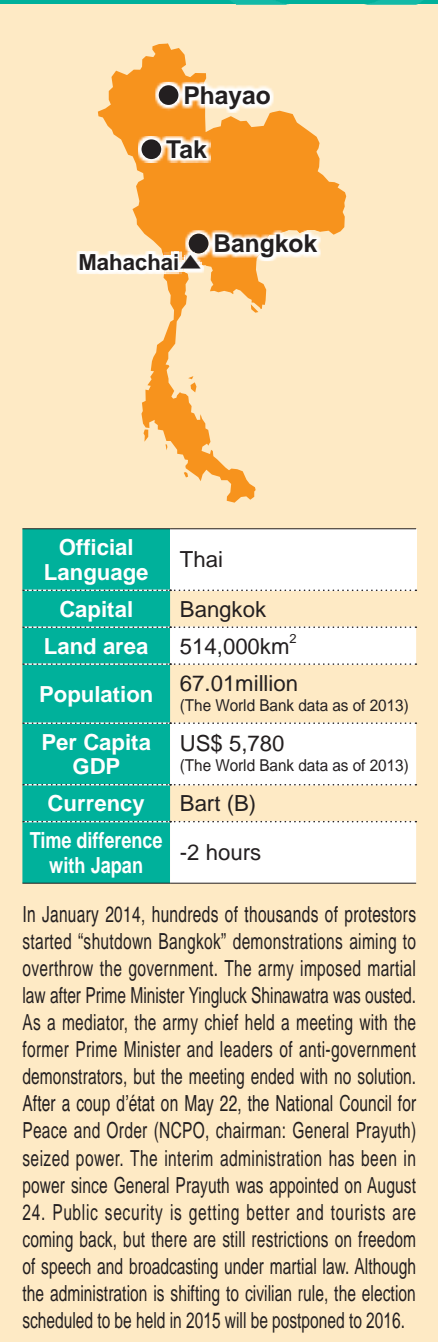

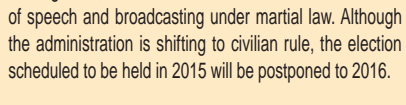

The number of immigrant workers from neighbor- book cases to 23 schools. These are going to be ing countries, especially from Cambodia, is increasing in Bangkok including Khlong-Toei. The creasing in Bangkok including khiong-Teel. The
number of Cambodian children who come to the Khlong-Toei community library is also increasing. The Khlong-Toei community library finished its repair work and opened on "November 29. The guage book corner for Cambodian, Burmese, Laotian and English books and an internet information search corner.

Based on this community library, the SVA started to provide mobile library services at Mae Sot disimmigrant workers live, the Mahachai distric in Samut Sakhon Province and slum areas in Bangkok. The SVA donated 30 books translated wearing their own national costumes.
to Burmese, a set of library boxes and library

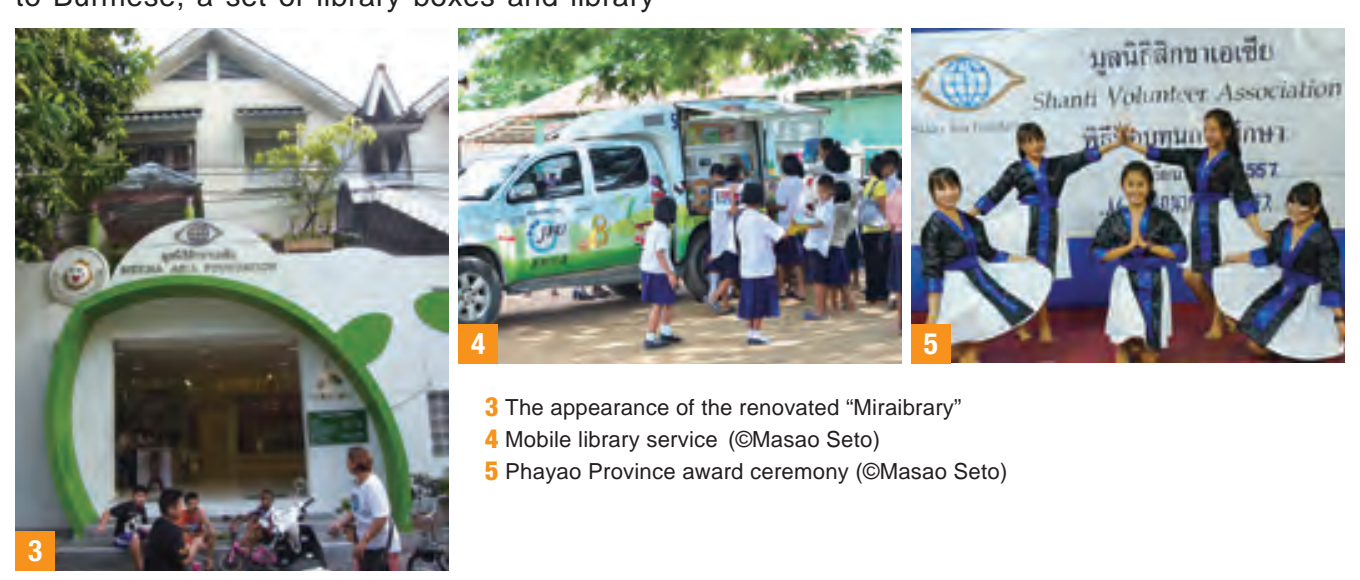

The SVA provided scholarships to 377 junior and senior high school students as well as to college
students from Bangkok, Phayao Province, Tak Province, and Loei Province. 88 representatives of scholarship students gathered from three
scholarship regions to the Shanti Student Dormitory in Pon district in Phayao Province and attended a three-day scholarship camp. The theme for the camp was to train model leaders Who have volunteering spirits." "Students who the natural park that the local people proseted repairing dormitories, and having culturtchange party by showing traditional dances อเชีย

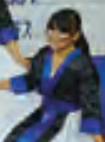
perent

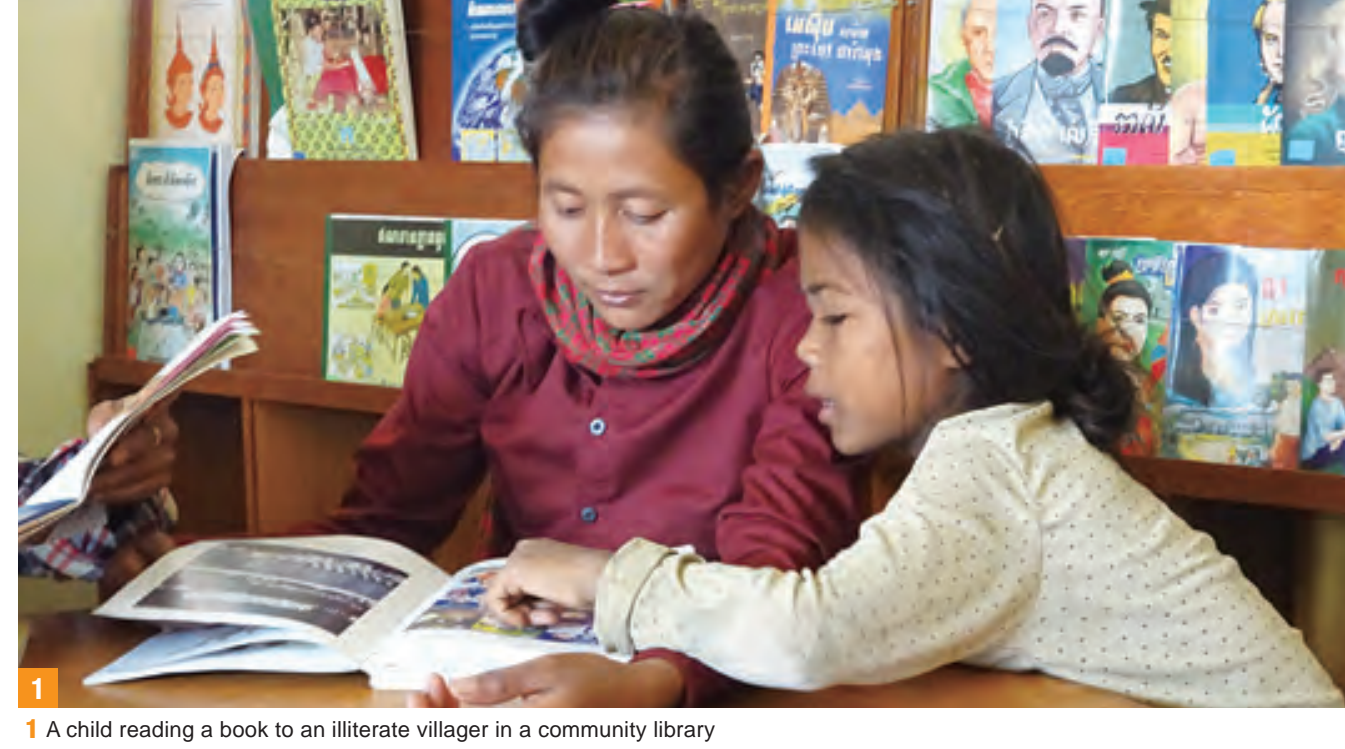

Elementary school enrollment rate has reached promoting reading activities and developing a co$97 \%$ but the percentage of the students who in Cambodia, the worst number in the South East Asian nations Asian nations where data are available. The per-
centage of disadvantaged children is about $33 \%$. In rural farming areas, the literacy rate of adults is currently less than $50 \%$. The SVA established
its local offices in Siem Reap Province and Batits local offices in Siem Reap Province and Bat-
tambang Province to deal with these issues by
kindergartens ducationally underprivileged areas. In line with the Ministry of Education, Youth and Sport policy develop human resources, the SVA conducted six projects and provided reading and educational environments to 151,393 people. As a new project, the SVA planned a project to enhance the quality of early childhood education in public

\section{Main Achievements}

(c) Dream Elementary School Project The SVA constructed eight elementary school buildangs and six libraries in Banteay Meanchey on school and library management. According to a follow-up survey for target schools in 2012 the rate of children going to the next grade and the dropout rate improved in three out of five

Schools. Q School Library Operation Project with Community Participation

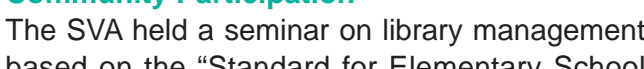
Libraries" of the Ministry of Education, Youth and Sport in eight schools in Banteay Meanchey and Battambang Provinces. The SVA donated decorations, equipment and books for libraries and conducted the reading promotion activities. 58 people from eight schools attended the seminar in the events for promoting library activities. The SVA is a member of a working group to create a "reading promotion guideline" in cooperation wit the Ministry of Education, Youth and Sport.
B Project for Publishing Picture Books (3) Project for Publishing Picture Books and Picture-Card Shows picture-card show and distributed them by
March, 2015. The survey on the books found that children like the published picture books: (4) Community Learning Center Project Centered on Library Activities The first Community Learning Center in Kampong Thom Province and the second in Siem dents, children and advits, used the libraries. and an averaes of more the 100 pepple cames to both libraries per day. More than 400 tites of books, including agriculture and heath related books indispensable for improving their living, are read by these people. The SVA planned a Seminar on improving the standard of living of

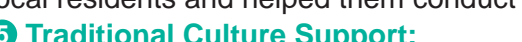

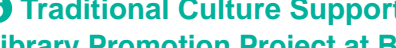

The SVA established a Buddhist Libras School Group (BLWG) in the Buddhist Institute and Buddhist Education Working Group (BEWG) in The Buddhist Education oftice.
The SVA opened a Buddhist library in Buddhist schools of taryet temples and conducted library these libraries. For BEWG, the SVA dent ded human resources to enhance the Buddhis school's quality by holding seminars tor formulatIng the plans and budget documents. The SVA constructed one community library in the Akpiwat Meanchey slum. In the five target slums, the SVA carried out mobile library activlies as planned. The SVA will recruit and train volunteers who will play a role for mobile library

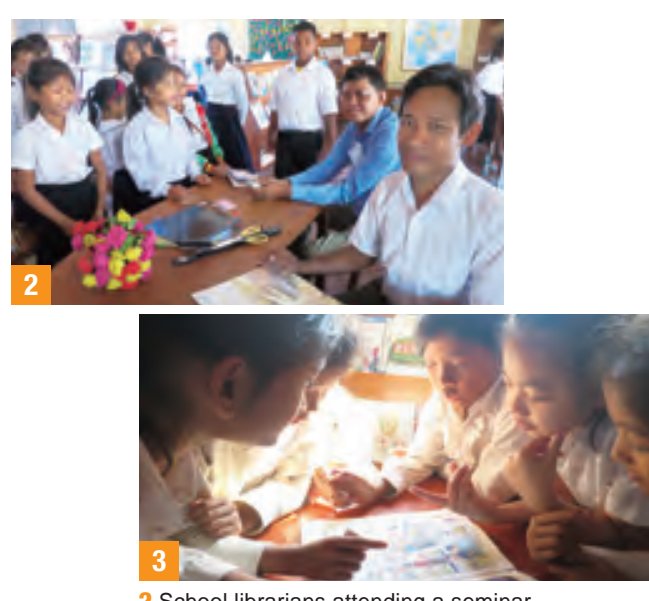

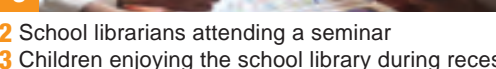

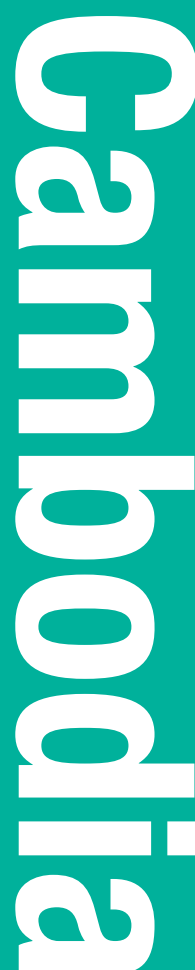

Mat
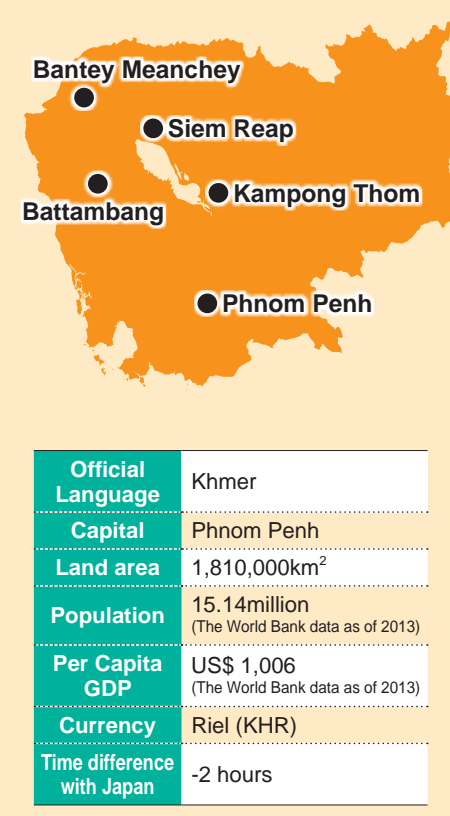

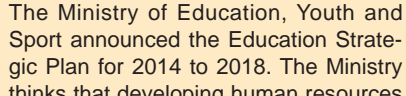
thinks that developing human resources
is an essential component tor its eco-

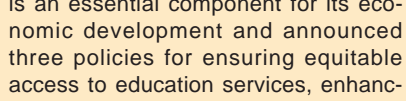

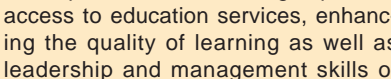

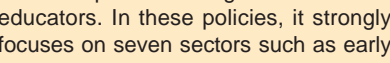

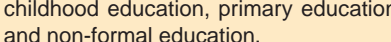

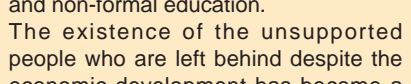




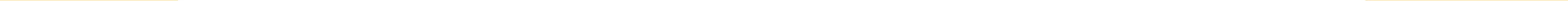




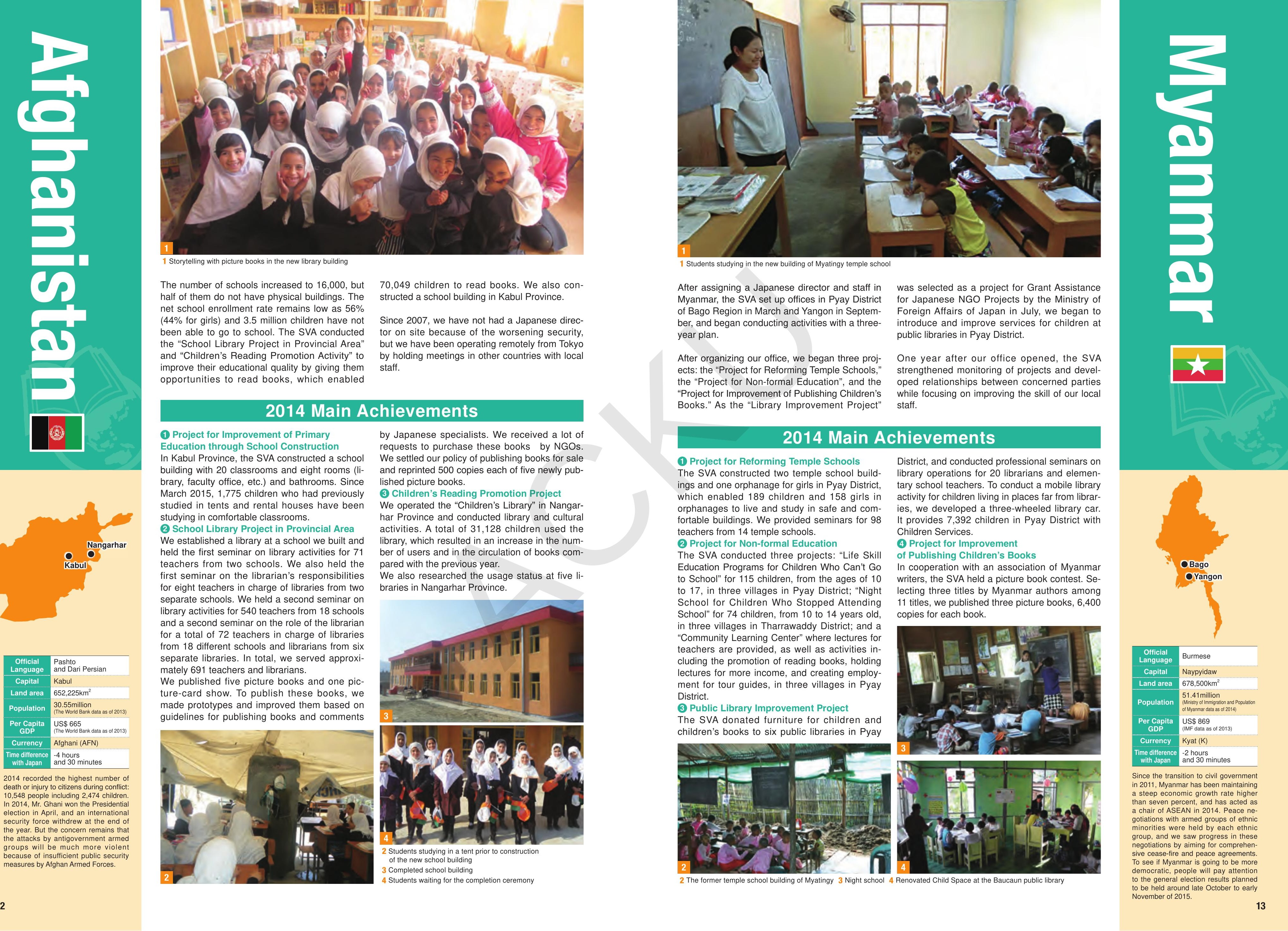




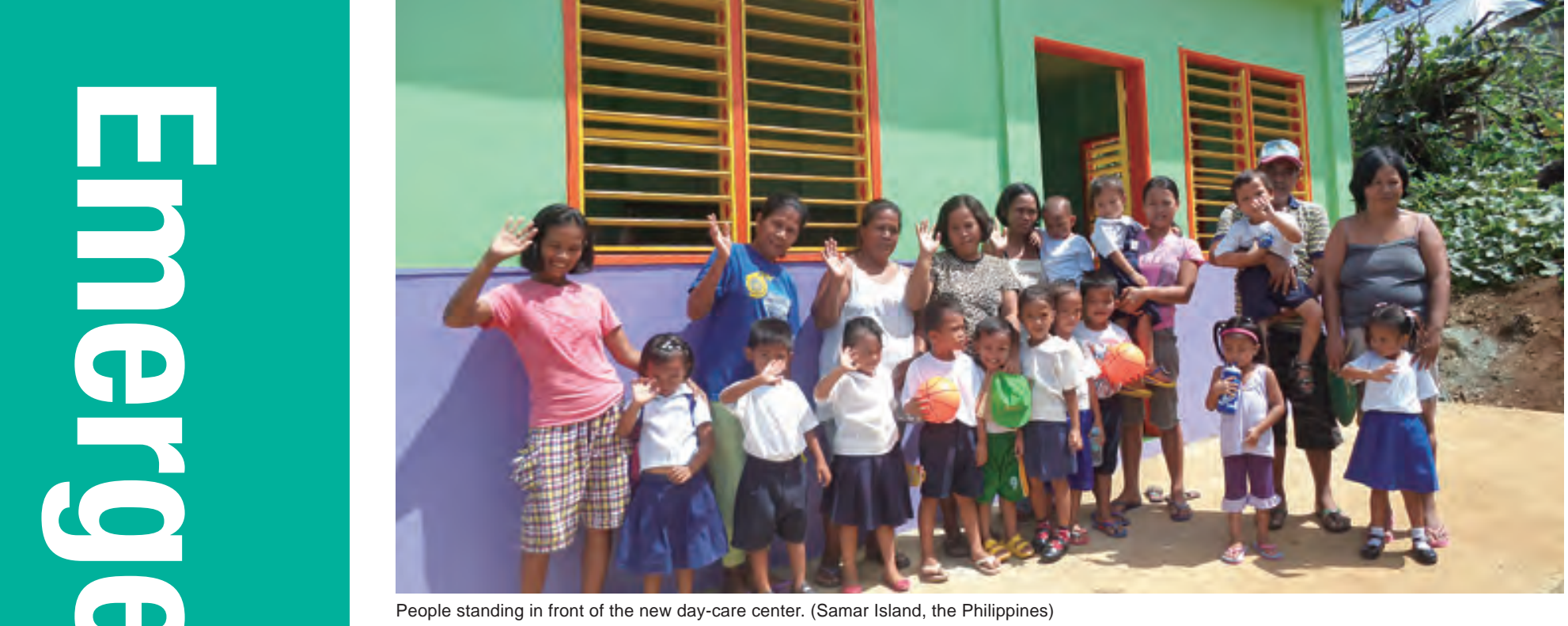

The support activities by the SVA for those affected by the Great East Japan Earthquake mark
the 5 th year in 2015 . In some areas, changes the 5 th year in 2015. In some areas, changes
towards reconstruction and securing fair living lowards reconstruction and securing fair living
standards have become evident as many people standards have become evident as many people
moved from temporary housing to public housing allocated for disaster victims. On the other
hand, healing the hidden psychological wounds

caused by the Fukushima power plant accident is still a big challenge. Responding to such will start terminating som areas and victims, we our reconstruction support will continue in fiscal 2015 in three prefectures, i.e., Iwate, Miyagi and

\section{Emergency Support Activities Overseas}

Typhoon Damage in the Philippines and Earthquake Damage in Yunnan, China in fiscal 2014

SVA continued support activities in fiscal 2014 in Municipality of Quinapondan, Eastern Samar was hit by the typhoon on November 8,2013 We supplied materials such as galvanized sheets and plywood, and tools such as hammers an nails, to repair and/or rebuild houses for 2,152 households in 16 villages. We restored five buildings of a day-care center, which provides educaconducted a trauma treatment program for them and their parents. The solidly-rebuilt day-care center served as a shelter for the local people in the subsequent typhoons and a mother who took
part in the program said, "Now I understand what

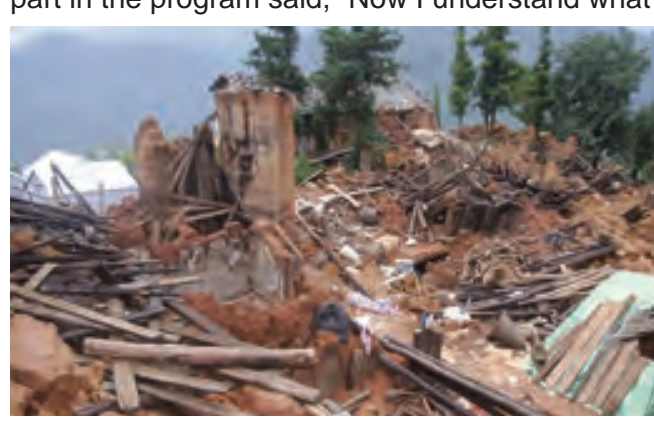

Damages in Huodehong Zhen after one month
from the earthquake (Yunnan Province, China) my family should do in times of disasters.

A 6.5-magnitude earthquake occurred in Ludian County of Zhaotong City in Yunnan Province, China on August 3, 2014, hitting poor Preas in the mountains. Shanti supplied cookand able gorge, where virtually no reliet supply was provided, Furthermore, we supplied futons, floor mats, cold-proof inner shirts, and down jackets in six locations of Huodehong Zhen who had to live in temporary tents and needed whe cold to survive the harsh

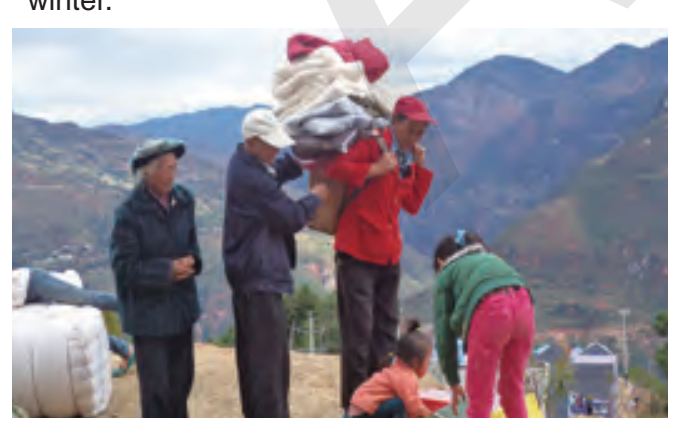

Affected people taking down jackets
supplied by SVA (Huodehong Zhen, China)

Approach to Disaster Prevention

Twenty years have passed since the Great Han- disseminate to the world the lessons we have shin-Awaji Earthquake and "The Third UN World Conference on Disaster Risk Reduction" was held in Sendai in March, 2015. Since disaster the Great East Japan Earthquake and the sublearned. Therefore, Shanti gave a presentation at a side-event of the World Conference on its areat Est dacted in the areas affected by the sequent nuclear accident, Japan is expected to

Reports from Three Disaster Support Offices of the Great East Japan Earthquake Wa - FROM PERSON TO PERSON - Kesennuma Reconstruction Project

2014 Activity report

By conducting the mobile library project and the library movement along with operating a library more than 10,000 people visited and borrowed about 23,000 books. In the town of Yamada, we co-operate the mobile library in partnership with it board of education. In Ofunato City, we discussed library activities at public restoration housings and at the Sanriku Community Center with employees of the municipal library and members of "Ohanashi-kororin" (a volunteer group for reading to "Rikuzentakata Community Library Users Group," which is actively supporting the library operation by holding events.

Plan for 2015

S Support the autonomous operation of new groups organized by staff members of Plan projects for children or community development

experience, hands-on learning and participation in community development by exploring the local area on foot

Support collaborations among those in fishing ind
men's group, in an effort to revitalize fishing villages

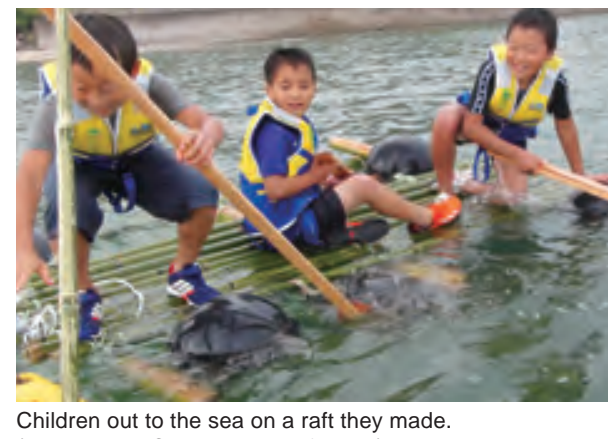

"Run in Tohoku!" - Mobile Library Project of Iwate Office

2014 Activity repor

By conducting the mobile library project and the library movement along with operating a library, more than 10,000 people visited our facilities and borrowed about 23,000 books. In the town of Yamada, we co-operate the mobile library in partnership with its board of ed allon. In of Center with employees of the municipal library and members of "Ohanashi-kororin"
(a volunteer group for reading to children). In Rikuzentakata City, the locals living in and around the city organized the "Rikuzentakata Community Library Users Group," which is actively supporting the library operation by holding events.

Plan for 2015

- Conduct mobile library activities and library movement, and operate community libraries (In Yamada Town, operation of mobile library activities is entrusted by the Board of Education)

- Discuss future library services with staff of Ofunato Municipal Library and memDiscuss ideal state of a community libray

munity Library Users Group" and execute ideas

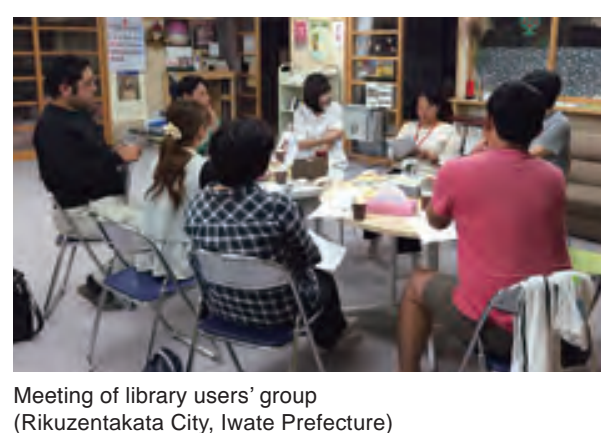

"Run in Tohoku!" - Mobile Library Project of Yamamoto Office

2014 Activity report es where 2,083 users borrowed more than 4,000 books. In Minamisoma City, the service was extended to Haramachi area and the number of service locations was increased from 8 to 12 in 2013. We had about 1,700 users borrowing approx. 3,000

Volunteers from Bookoff Corporation Limited were supporting the project in the town Branch of Fukushima Sotoshu Young Priests Association and The Prudential Gibrat tar Financial Life Insurance Co., Ltd.

Plan for 2015

- Conduct mobile library activities

Support conducting and continuing activities for socially vulnerable children and

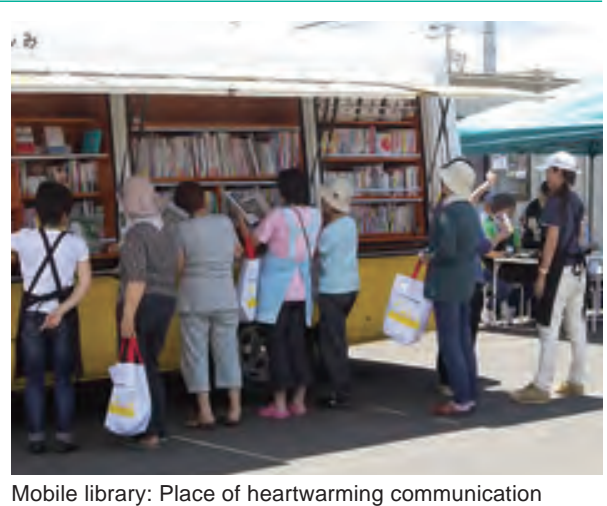

Community Reconstruction Initiative Following Lifting of Evacuation Order

for Areas within the 20km-radius of Disaster-struck Nuclear Power Plant in Fukushima Plan for 2015

Minamisoma City where SVA conducts mobile library activities, the evacuation order is expected to be lifted in 2016 for the evacuees mainly from Odaka area and environs within the $20 \mathrm{~km}$-radius of the nuclear power plant. After a long absence of five years evacuees will begin retuing the risks of nuclear power plants and make every effort to make their everyday life comfortable. We will support those who decide return home but have anxieties about their daily life as well as on radiation and potential acciden 


\section{$E$ \\ (3)

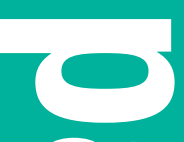 \\ $\infty$ \\ 5 \\ $\bullet$}

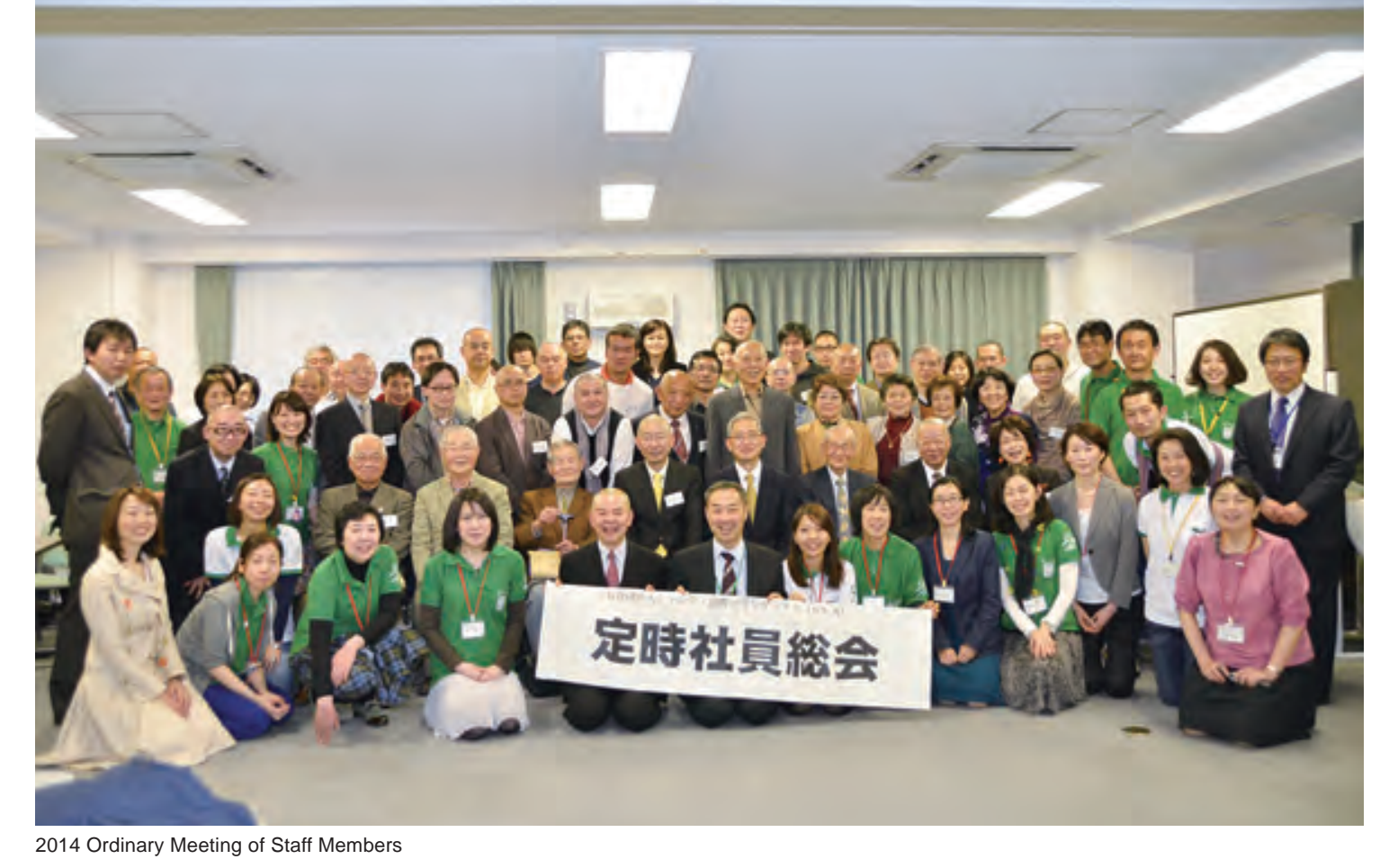

We would like to express our gratitude for your warm support, which enabled us to continue our activities in 2014.

By making efforts to disseminate the name and activities of Shanti, we succeeded in welcoming 1,122 Individuals and 263 companies/organizations as our new supporters.

We will further promote our activities and work to develop stronger relationships with you.

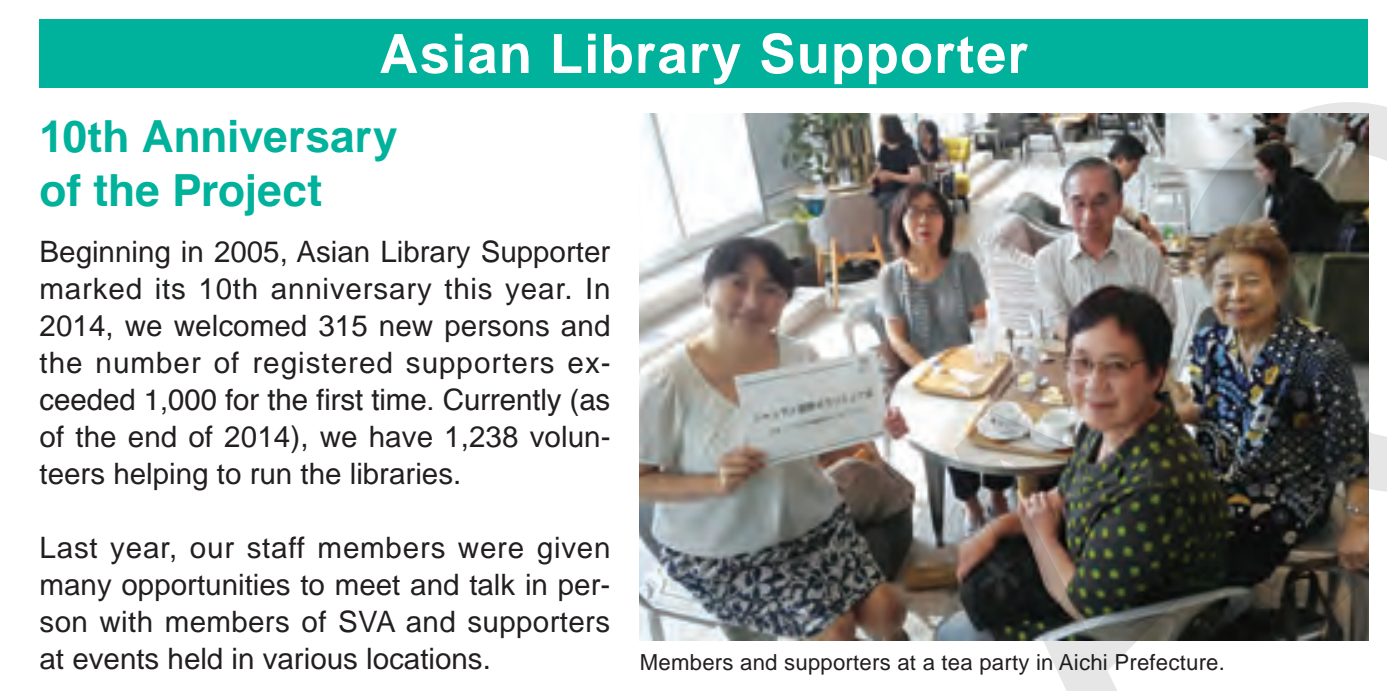

Campaign for Delivering Picture Books

Delivery of picture books to children in Myanmar begins

With the support of many people nation-
wide, we had been able to deliver 15,179 wide, we had been able to deliver 15,179
picture books to the areas we are active in. picture books to the areas we are active in.
We started the same campaign in Myanmar, where we newly opened our office, and 634 books are to be delivered to the children there. In fiscal 2014, our activities were supported by 1,215 individuals, companies, and schools. The number of books
delivered to the designated areas exceeded delivered to the designated areas exceeded
240,000 since the beginning of this cam240,000 since
paign in 1999.

In fiscal 2015, we will ask for further coop-
The Power of Books is

the Power to Live

In 2014, the first fiscal year of our five-year mid-term action plan, the SVA developed the copy "The power of books is the power to live to disseminale our acliviles. We crealed a specta companies and celebrities.

We held ten sessions/events to directly report on our activities to 343 participants.

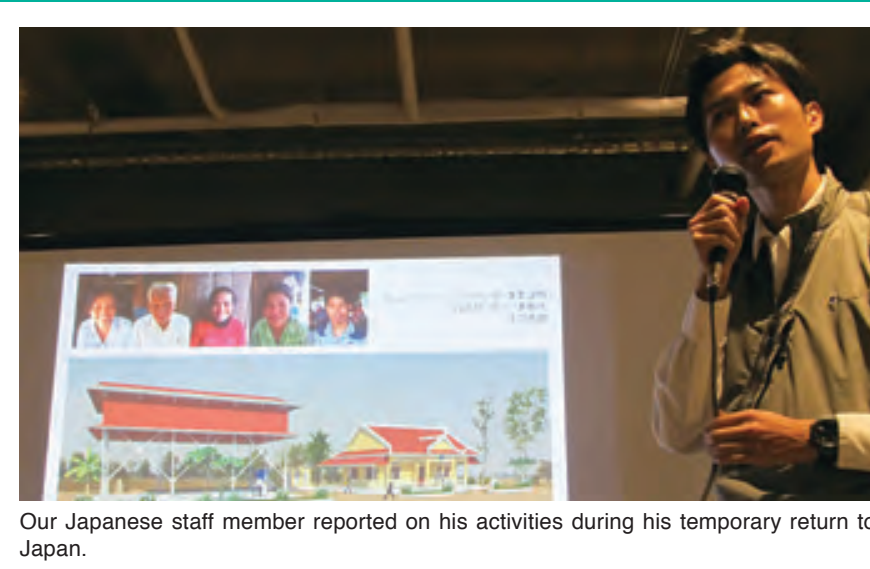

Contribution Project: Providing Items

The more you sort out,

the more you contribute to society

This project calls for donations of books, CDs, and DVDs. In addition to "BOOKOFF Online specializing in novels and man ness and medical fields joined the project.

In cooperation with "Otakaraya” (Meguro Yamate-dori St. Shop), bags, cameras, mobile phones and commemorative coins.

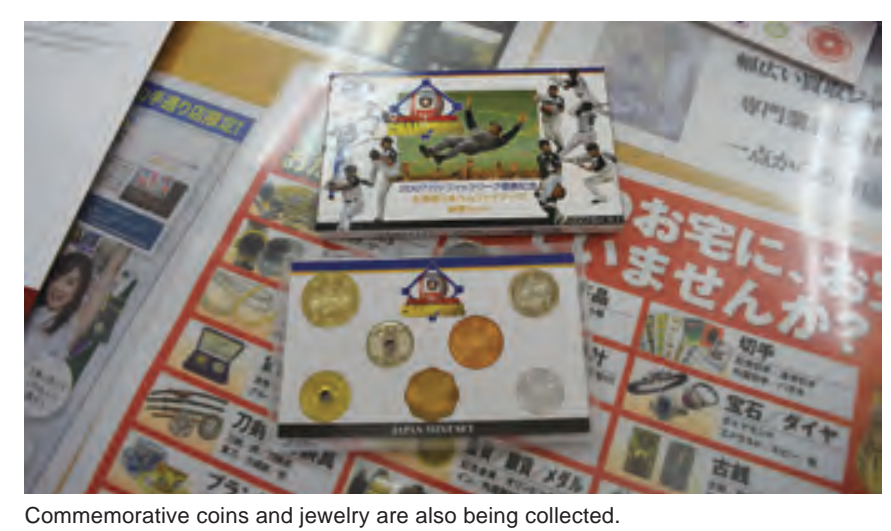

\section{Craft Aid}

Develops brand new products with designer

In collaboration with Mr. Teppei Fujita, a pro bono designer, we developed brand new craft products. Learning directly from the culture, techniques, and the conditions of the local manufacturers in Thailand and Cambodia, we manufactured the products
with thoughts on what must be done for the region. While placwith thoughts on what must be done for the region. Whilue on what we have accumulated as tradition, we ing great value on what we have accumulated as tradition,
are creating a new stream to develop new products and cultivate new customers (shops).

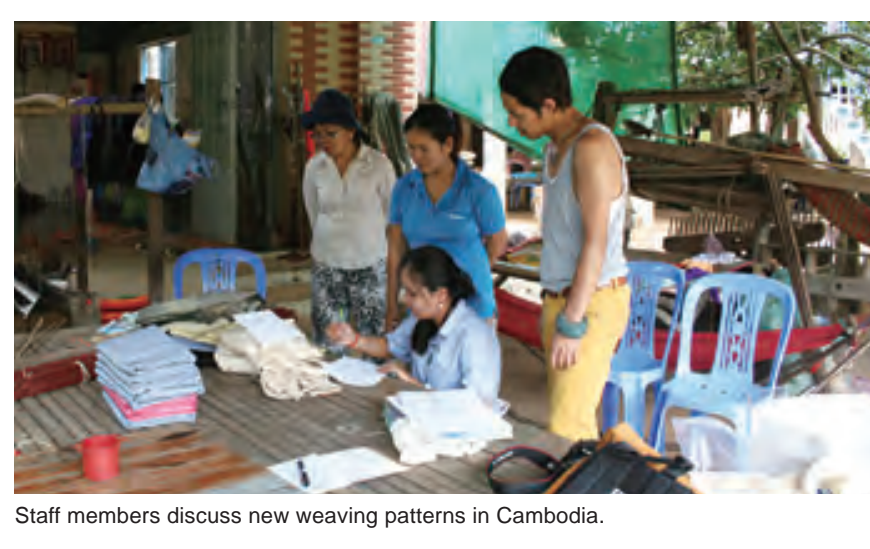

Support for Overseas Projects

Beyond the sea,

meeting people via books

To endeavor and expand our activities in Myanmar, a new locawe formed a new project for early childhood education and hald traning sessions to support the local people with a view of protecting the human rights of those involved.

In 2014, the SVA constructed 14 buildings as elementary schools, and nine buildings and one room as libraries. We also shows to support the reading promotion activities.

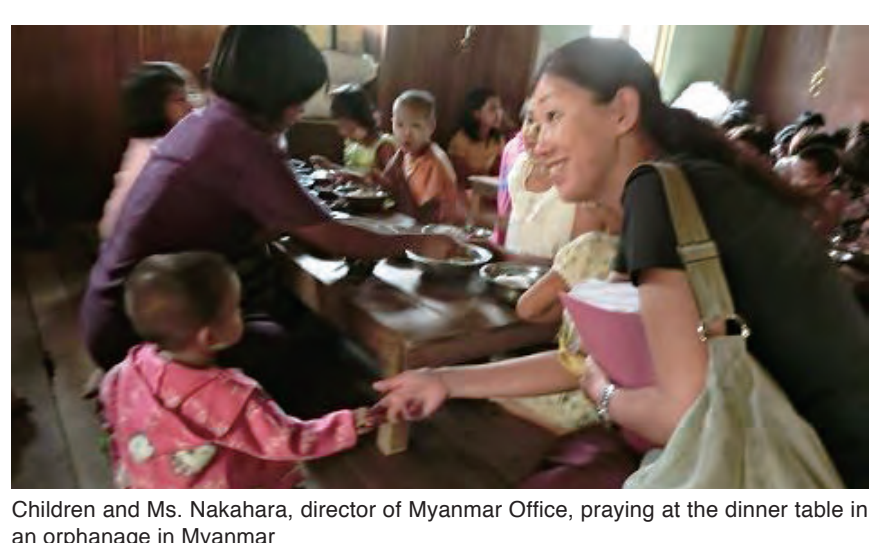


Financial Report

\begin{tabular}{|rr|}
\hline Income & Year 2014 \\
\hline Bank Interest & 132,870 \\
\hline Membership Fee & $27,255,000$ \\
\hline Donation & $411,927,824$ \\
\hline Subsidy & $275,825,183$ \\
\hline Programs for Profit & $97,375,013$ \\
\hline Others & $4,493,631$ \\
\hline Total & $\mathbf{8 1 7 , 0 1 0 , 5 2 1}$ \\
\hline
\end{tabular}

\begin{tabular}{lr}
\hline Expenditures & Year 2014 \\
\hline Public Interest Purpose 1 & \\
\hline Thailand & $15,059,816$ \\
\hline Cambodia & $152,424,903$ \\
\hline Laos & $31,710,753$ \\
\hline Myanmar (Burma) Refugee & $59,845,725$ \\
\hline Afghanistan & $150,430,575$ \\
\hline Myanmar & $43,995,139$ \\
\hline Others & $39,361,915$ \\
\hline Public Interest Purpose 2 & \\
\hline The Great East Japan Earthquake & $123,337,874$ \\
\hline Emergency Relief(Overseas) & $86,484,311$ \\
\hline Others & $3,546,147$ \\
\hline Public Interest Purpose 3 & $69,249,963$ \\
\hline Public Interest Purpose (Common) & $9,435,662$ \\
\hline Total: Public Interest Purpose & $\mathbf{7 8 4 , 8 8 2 , 7 8 3}$ \\
\hline Profit-making Purpose & $\mathbf{4 1 , 2 2 8 , 3 7 5}$ \\
\hline Administration & $\mathbf{2 0 , 2 6 8 , 8 1 5}$ \\
\hline Grand Total & $\mathbf{8 4 6 , 3 7 9 , 9 7 3}$ \\
\hline
\end{tabular}

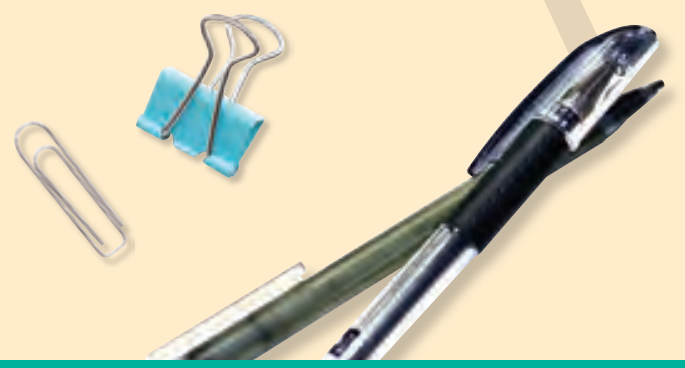

SVA Association members

Total number of members

Staff member

Individual

Organization

Supporting member

Individual

Organization

Honorary President

Rev. Zendo Matsunaga

\section{Advisor}

Mr. Fusao Adachi

Rev. Hojun Abe

Mr. Masahiro Onoda

Rev. Eisho Kawahara

Mr. Takashi Shiraishi

Rev. Sojun Matsuno
1,868 persons

308 persons

256 persons

52 organizations

1,560 persons

1,372 persons

188 organizations

(as at December 31, 2014)

\section{SVA Executive Board members}

President

Rev. Kyoei Wakabayashi

Vice President

Rev. Gido Sambe

Ms. Kayoko Kozu

Chief Executive Director

Rev. Shunko Chino

Managing Director

Ms. Hitoshi Ichikawa

Prof. Tatsuya Hata

Rev. Bunmei Hayasaka
Technical Adviser Ms. Ryoko Sato Mr. Yoshifumi Tajiri Ms. Yayoi Tanaka Mr.Toshiyuki Osuga

\section{Shanti Volunteer Association}

\section{Jibokaikan 2,3F, Daikyo-cho, Shinjuku-ku, Tokyo}

\section{Phone +81-3-5360-1233 FAX +81-3-5360-1220}

\section{Email info@sva.or.jp Official Website http://sva.or.jp/english/about/}

Published by Shanti Volunteer Association

Translated by International Language Volunteers of the Tokyo YWCA

翻訳担当者: 根本、小泉、中尾、村越、黒木

プルーフリード : 大森、田中、Simmer

コーディネーター: 汁本、久宗

All rights reserved,October 2015 